\title{
EQUITY
}

Vol. 23, No.2, 2020, 189-200

DOI: 10.34209 /equ.v23i2.2236

P-ISSN 0216-8545 | E-ISSN 2684-9739

Diunggah : November 2020

Diterima : Desember 2020

Dipublikasi : Desember 2020

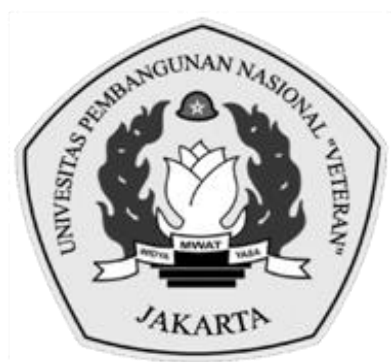

\section{STUDI LITERATUR TENTANG CLOUD ACCOUNTING}

\author{
Andy Setiawan ${ }^{1 *}$, Praptiningsih Praptiningsih ${ }^{2}$, Nurhafifah Matondang ${ }^{3}$ \\ 1andysetiawan2285@upnvj.ac.id, 2praptiningsih@upnvj.ac.id, \\ 3nurhafifahmatondang@upnvj.ac.id \\ 1,2,3Universitas Pembangunan Nasional Veteran Jakarta, Indonesia \\ *Penulis Korespondensi
}

\begin{abstract}
Abstrak
Penelitian ini membahas berbagai literatur penelitian mengenai cloud accounting di Indonesia serta pengembangan penelitian dimasa depan. Penelitian mengenai cloud accounting di Indonesia masih terbatas secara kuantitas dan kualitas sub tema. Perancangan sistem, evaluasi dan persepsi pengguna aplikasi merupakan sub tema utama penelitian cloud accounting di Indonesia. Pengembangan sub tema penelitian bisa dilakukan dari berbagai perspektif baik dari sisi penyedia jasa, pengguna jasa, akuntan dan lembaga profesi akuntan serta stakeholder. Keterbatasan penelitian yang membahas mengenai cloud accounting merupakan sebuah peluang untuk mengembangkan tema ini dari berbagai perspektif.
\end{abstract}

Kata Kunci: Studi Literatur; Akuntansi Awan; Akuntansi Online; Akuntansi Berbasis Web

\begin{abstract}
This study discusses the various research literature on cloud accounting in Indonesia as well as the development of future research. Research on cloud accounting in Indonesia is still limited in terms of quantity, and quality of sub-themes. System design, evaluation and the perception of application users are the main sub-themes of cloud accounting research in Indonesia. The development of research subthemes can be carried out from various perspectives from the service providers, service users, accountants, and professional accounting institutions and stakeholders. The limitation of research that addresses cloud accounting is an opportunity to develop this theme from various perspectives Keywords: Literature Study; Cloud Accounting; Online Accounting; Web-Based Accounting
\end{abstract}

\section{PENDAHULUAN}

Perkembangan teknologi informasi di era revolusi industri 4.0 tidak hanya berdampak dalam manajemen bisnis tetapi juga telah mempengaruhi proses akuntansi di perusahaan. Salah satunya adalah penggunaan teknologi komputasi awan (cloud computing) dalam menyelesaikan siklus akuntansi. Sistem informasi akuntansi memiliki peranan penting sebagai penyedia informasi keuangan dalam pengambilan keputusan di organisasi (Christauskas \& Miseviciene, 2012). Teknologi internet telah memudahkan untuk memproses berbagai informasi

Mengutip ini sebagai: Setiawan, A., Praptiningsih, P. \& Matondang, N. 2020. Studi Literatur tentang Cloud Accounting. Equity, 23(2), 189-200. doi.org/10.34209/equ.v23i2.2236 
ekonomi perusahaan yang akan membantu pengambil keputusan dalam menentukan berbagai kebijakan, dan salah satu sumber informasi yang dapat diandalkan. Oleh karena itu, pemilihan teknologi yang akan digunakan sebagai alat bantu penyusunan laporan keuangan menjadi kunci utama yang wajib diperhatikan, kesalahan dalam pemilihan platform teknologi akan menyebabkan informasi yang dihasilkan menjadi tidak akurat dan dalam jangka panjang akan berpengaruh terhadap kelangsungan hidup perusahaan.

"Cloud" secara sederhana identik dengan internet. "Cloud" merupakan tempat penyimpanan informasi dan data di server internet yang dapat diakses dengan mudah melalui berbagai perangkat digital seperti komputer, laptop, smartphone maupun perangkat teknologi lainnya, yang terkoneksi dengan jaringan web (Bean, 2010). Beberapa contoh penggunaan layanan cloud adalah email, google drive dan media sosial. Data yang diunggah oleh pengguna tersimpan di perusahaan penyedia jasa secara gratis maupun berbayar. Teknologi terbaru menyebabkan perubahan cara kerja sistem akuntansi di perusahaan (Singerová, 2018). Peningkatan kompleksitas lingkungan bisnis sejalan dengan kompetisi global yang harus dihadapi perusahaan, berpengaruh pada profesi akuntan (Dimitriu \& Matei, 2014). Akuntan dituntut untuk mampu beradaptasi dengan perkembangan teknologi terkini. Dalam era globalisasi, kemudahan untuk memperoleh data darimana saja dan kapan saja menjadi sebuah kebutuhan (Wyslocka \& Jelonek, 2015). Dengan teknologi cloud, data informasi keuangan dapat dengan mudah diakses dan dikelola oleh Akuntan. Keuntungan dari layanan cloud termasuk peningkatan efisiensi, fleksibilitas, kemudahan akses dan penggunaan, serta kemampuan untuk memproses sejumlah besar informasi (Popivniak, 2019). Di balik kelebihannya, layanan cloud juga memiliki risiko signifikan terhadap pengguna, yaitu keamanan data (Popivniak, 2019).

Penelitian mengenai cloud accounting, akuntansi digital dan pengaruh teknologi informasi terhadap akuntansi semakin meningkat dalam beberapa dekade ini. Akan tetapi isu penelitian ini belum terlalu menjadi perhatian di Indonesia. Hal ini dapat terlihat dari masih sedikitnya penelitian dengan tema ini di Indonesia. Pada saat dilakukan pencarian literatur melalui google scholar di bulan Agustus 2020 dengan keyword sebagai berikut : "Akuntansi Digital" OR "Akuntansi Online" OR "Akuntansi Awan" OR "Akuntansi Mobile", maka daftar jurnal penelitian yang sesuai dengan kata kunci tersebut masih sedikit. Padahal di Indonesia sendiri saat ini perkembangan perangkat lunak akuntansi berbasis online mulai meningkat. Salah satunya di google play store banyak tersedia perangkat lunak akuntansi berbasis aplikasi dan dapat diakses melalui smartphone baik yang gratis maupun berbayar. Contoh salah satu aplikasi yang dapat diunduh secara gratis adalah SIAPIK. SIAPIK merupakan aplikasi akuntansi sederhana yang dapat digunakan oleh pelaku UMKM, aplikasi ini dibuat oleh Bank Indonesia. Penyedia software akuntansi dalam negeri yang sebelumnya berbasis desktop (software tradisional yang perlu diinstal ke komputer) mulai menawarkan produk berbasis cloud mereka, diantaranya Accurate Online, Zahir Online dan Jurnal.id. Penelitian ini berfokus pada studi literatur penelitian cloud accounting di Indonesia dan prospek pengembangan penelitian dimasa depan berdasarkan hasil riset di dunia. Selanjutnya, penelitian ini diharapkan menjadi langkah awal dalam 
penelitian tentang cloud accounting di Indonesia, yang masih kurang dalam diskusi tentang masalah ini.

\section{TINJAUAN PUSTAKA}

\section{Cloud Accounting}

Tahap pertama pengembangan teknologi yang berpengaruh terhadap praktek organisasi perusahaan dan akuntan dimulai antara tahun 1960-1970 pada saat penerapan sistem informasi yang berbasis komputer mulai dikenalkan, pada tahap ini akuntan mulai melakukan input data dengan lebih rapih dan tertata sehingga dapat memberikan analisis yang jauh lebih akurat mengenai kondisi keuangan perusahaan (Granlund \& Mouritsen, 2003; Knudsen, 2020; Porter \& Heppelmann, 2014). Tahap kedua dimulai pada akhir tahun 1990an dan awal 2000, ditandai dengan pengembangan di bidang internet dan penggunaan perangkat lunak Enterprise Resource Planning (ERP) yang memungkinkan akuntan menghasilkan dan memperoleh informasi dari seluruh divisi perusahaan dengan lebih efektif dan efisien (Knudsen, 2020). Tahap ketiga sedang berlangsung saat ini, era ini disebut dengan "digitalisasi". Era dimana pengembangan dan kombinasi berbagai teknologi telah mempengaruhi bagaimana proses operasional perusahaan dan termasuk cara kerja akuntan (Karimi \& Walter, 2015; Knudsen, 2020).

Salah satu produk yang dihasikan dari proses digitalisasi di bidang akuntansi adalah cloud accounting. Perangkat lunak akuntansi tradisional biasanya digunakan dengan cara diinstal kedalam perangkat komputer pengguna (users), sedangkan cloud accounting adalah sebuah jasa dan bukan sebuah produk barang (Dimitriu \& Matei, 2015). Perusahaan pengguna membeli jasa perangkat lunak akuntansi yang disediakan oleh penyedia jasa (provider) dengan lisensi dan perangkat tambahan lain yang diperlukan, serta dapat diakses melalui komputer atau perangkat teknologi lainnya yang terhubung dengan jaringan internet (Dimitriu \& Matei, 2015). Dengan menggunakan jasa ini, perusahaan pengguna membayar biaya hosting kepada provider secara bulanan atau tahunan. Perusahaan provider akan melakukan pembaharuan sistem secara berkala, melakukan backup data, serta memberikan bantuan jika terjadi kendala teknis yang dialami oleh pengguna (Sadighi, 2014). Perangkat lunak akuntansi yang menggunakan platform aplikasi mobile (mobile apps) dari Google Play Store atau App Store, berbasis web (web based), atau software akuntansi online lainnya termasuk kedalam bentuk layanan cloud accounting.

Ada beberapa hal yang menjadi alasan bagi sebuah perusahaan untuk memilih menggunakan layanan berbasis cloud menurut Khanom (2017) diantaranya :

1. Menjaga fokus bisnis perusahaan: Dengan memilih layanan cloud, perusahaan dapat lebih fokus mengembangkan bisnis intinya, dibanding harus memikirkan pengembangan perangkat lunak dan keamanan data mereka. Perusahaan dapat menjalankan usaha dengan lebih efisien, sehingga kelebihan dana yang dimiliki dapat diinvestasikan kedalam pengembangan bisnis perusahaan.

2. Business Agility: Secara ringkas business agility adalah kemampuan perusahaan untuk berkembang secara dinamis mengikuti perkembangan zaman, teknologi, persaingan usaha dan kondisi terkini di bidang usaha yang perusahaan geluti. Dengan penggunaan teknologi cloud, perusahaan yang memiliki keterbatasan di bidang teknologi dapat mengikuti 
perkembangan teknologi terkini melalui pembaharuan yang dilakukan oleh provider dengan biaya yang jauh lebih murah.

3. Mengurangi biaya modal: Biaya modal yang harus dikeluarkan untuk membuat pusat data (data center) perusahaan atau membeli perangkat lunak tradisional, digantikan dengan beban bulanan untuk berlangganan jasa cloud yang jauh lebih murah dan terjangkau bagi perusahaan kecil atau UMKM.

4. Skala Bisnis: Perusahaan pengguna dapat memilih layanan cloud yang mereka butuhkan, disesuaikan dengan kondisi usaha dan skala bisnis yang dimiliki.

5. Kemudahan Akses: Dapat melakukan usaha tanpa batasan ruang dan waktu. Perusahaan pengguna dapat mengakses data perusahaan kapanpun dan dimanapun selama ada koneksi internet yang memadai.

6. Efisiensi Tenaga Kerja : Perusahaan dapat mengurangi tenaga kerja di departemen TI.

Proses akuntansi yang dilakukan melalui cloud merupakan solusi yang inovatif bagi perusahaan kecil dan menengah karena dapat menghemat dana untuk pengembangan perangkat lunak akuntansi (Christauskas \& Miseviciene, 2012). Tabel 1 menjelaskan perbedaan antara pembelian lisensi perangkat lunak tradisional yang diinstal ke komputer perusahaan pengguna (users) dengan cloud.

Tabel 1. Perangkat Lunak Tradisional Berlisensi dan Berbasis Cloud

\begin{tabular}{lll}
\hline \multicolumn{1}{c}{ Aspek } & \multicolumn{1}{c}{ Berbasis Lisensi } & Berbasis Cloud \\
\hline $\begin{array}{l}\text { Lisensi Perangkat } \\
\text { Lunak Akuntansi }\end{array}$ & $\begin{array}{l}\text { Dibeli dari provider } \\
\text { atau dibuat sendiri } \\
\text { oleh perusahaan }\end{array}$ & $\begin{array}{l}\text { Disewa oleh } \\
\text { perusahaan }\end{array}$ \\
\hline Lokasi sistem & $\begin{array}{l}\text { Sesuai dengan } \\
\text { keinginan } \\
\text { perusahaan }\end{array}$ & Di Cloud \\
\hline $\begin{array}{l}\text { Hardware/ } \\
\text { Perangkat keras }\end{array}$ & $\begin{array}{l}\text { Disediakan oleh } \\
\text { perusahaan }\end{array}$ & $\begin{array}{l}\text { Sudah termasuk } \\
\text { dalam layanan } \\
\text { cloud }\end{array}$ \\
\hline $\begin{array}{l}\text { Windows \& SQL } \\
\text { Server }\end{array}$ & $\begin{array}{l}\text { Disediakan oleh } \\
\text { perusahaan }\end{array}$ & $\begin{array}{l}\text { Sudah termasuk } \\
\text { dalam layanan } \\
\text { cloud }\end{array}$ \\
\hline Biaya Perawatan & $\begin{array}{l}\text { Dikeluarkan oleh } \\
\text { perusahaan }\end{array}$ & $\begin{array}{l}\text { Sudah termasuk } \\
\text { dalam layanan } \\
\text { cloud }\end{array}$ \\
\hline
\end{tabular}




\begin{tabular}{lll}
\hline Sumberdaya TI & $\begin{array}{l}\text { Tim dari perusahaan } \\
\text { atau bekerjasama } \\
\text { dengan provider } \\
\text { diluar perusahaan. }\end{array}$ & Tidak dibutuhkan \\
\hline $\begin{array}{l}\text { Support/layanan } \\
\text { pendukung }\end{array}$ & $\begin{array}{l}\text { Dibeli dari provider di } \\
\text { luar perusahaan. }\end{array}$ & $\begin{array}{l}\text { Dibeli dari } \\
\text { penyedia jasa } \\
\text { layanan cloud }\end{array}$ \\
\hline & $\begin{array}{l}\text { Terbatas pada jumlah } \\
\text { Number of users }\end{array}$ & Tidak Terbatas \\
\hline Sumber: Christauskas \& Miseviciene (2012) &
\end{tabular}

\section{Keunggulan dan Resiko Cloud Accounting}

Kelebihan yang dimiliki oleh cloud accounting dibandingkan dengan perangkat lunak akuntansi tradisional terangkum dari berbagai penelitian (Christauskas \& Miseviciene, 2012; Dimitriu \& Matei, 2014; Khanom, 2017; Popivniak, 2019) sebagai berikut:

1. Biaya murah: Perusahaan pengguna (users) tidak perlu mengeluarkan biaya investasi untuk pembelian perangkat lunak akuntansi berlisensi atau mendirikan pusat data TI tersendiri. Pengurangan biaya staf TI untuk instalasi atau pemeliharaan data dan peralatan. Perusahaan juga dapat mengubah pengeluaran biaya modal (investasi) kedalam beban operasional bulanan dalam bentuk beban sewa layanan cloud accounting. Hal ini tentu saja sangat membantu perusahaan kecil atau UMKM yang memiliki keterbatasan modal.

2. Kemudahan Akses: Pengguna dapat mengakses berbagai informasi akuntansi melalui perangkat teknologi yang terhubung dengan internet tanpa dibatasi oleh tempat dan waktu. Pengguna juga dapat memberikan akses untuk berbagi informasi kepada pihak lain yang dikehendaki, sehingga memudahkan untuk melakukan koordinasi dan penyamaan informasi.

3. Fasilitas dan layanan: Perusahaan penyedia layanan cloud accounting menawarkan berbagai keuntungan bagi pengguna diantaranya pembaharuan sistem secara gratis, kapasitas penyimpanan data di server yang memadai, pemeliharaan dan pencadangan (back up) data, termasuk layanan keluhan pelanggan.

4. Real Time Information Updating: Setiap perubahan atau input data yang dilakukan oleh pengguna akan segera tercatat didalam sistem, sehingga setiap saat para pengguna dapat mengetahui kondisi terkini dari perusahaan.

5. Keamanan data: Setiap data yang tersimpan dijamin keamanannya oleh provider. 
Disamping berbagai kelebihan cloud accounting diatas, ada beberapa resiko, hambatan atau kendala yang mungkin dihadapi oleh pengguna layanan (Christauskas \& Miseviciene, 2012; Dimitriu \& Matei, 2014; Khanom, 2017) sebagai berikut:

1. Keamanan data : Kerahasiaan dan keamanan data merupakan salah satu isu penting yang dihadapi oleh penyedia layanan dan pengguna. Kemungkinan terjadinya kebocoran data bisa dialami dari sisi penyedia jasa maupun pengguna. Pihak yang tidak bertanggung jawab dapat melakukan kegiatan perusakan atau bahkan menghilangkan data. Ini yang menjadi salah satu alasan perusahaan belum menggunakan layanan cloud sebagai tempat pengolahan data keuangan mereka, dan lebih memilih untuk menyimpan datanya secara mandiri. Terutama lembaga yang mengolah data penting dan sensitif seperti bank atau institusi kesehatan.

2. Terbatasnya akses internet : Di area tertentu dimana belum terjangkau layanan internet atau memiliki koneksi internet yang tidak stabil, layanan cloud akan sulit untuk diakses.

3. Hilangnya kontrol : Perusahaan pengguna kehilangan kontrol atas perangkat lunak yang dimiliki, karena pengendalian penuh atas sistem dimiliki oleh penyedia jasa. Selain itu pengguna akan memiliki ketergantungan kepada penyedia jasa untuk melakukan pemeliharaan, pembaharuan, dan pengelolaan sistem.

\section{METODOLOGI PENELITIAN}

Dalam penelitian ini metode yang digunakan adalah melakukan studi literatur dengan analisis konten dari berbagai buku, jurnal penelitian dan referensi ilmiah lainnya di Indonesia yang membahas mengenai cloud accounting melalui google scholar pada periode tahun 2011-2020. Kata kunci atau keyword yang digunakan sebagai berikut: "Akuntansi Digital" OR "Akuntansi Online" OR "Akuntansi Awan" OR "Akuntansi Mobile". Tambahan kata kunci lainnya ialah "Cloud Accounting" dengan syarat penelitian dilakukan di Indonesia oleh peneliti Indonesia.

\section{HASIL DAN PEMBAHASAN}

\section{Penelitian Cloud Accounting di Indonesia}

Pada saat dilakukan pencarian literatur melalui google scholar di bulan Agustus 2020 dengan keyword sebagai berikut : "Akuntansi Digital" OR "Akuntansi Online" OR "Akuntansi Awan" OR "Akuntansi Mobile", maka daftar jurnal penelitian yang sesuai dengan kata kunci tersebut masih sedikit. Sedangkan kata kunci "Cloud Accounting di Indonesia" dalam google scholar memunculkan tambahan sub tema penelitian yang diangkat peneliti Indonesia namun diterbitkan di jurnal internasional.

Secara umum tema penelitian cloud accounting di Indonesia dalam jurnal penelitian dapat dibagi menjadi beberapa tema. Pertama, sub-tema perancangan. Dalam sub tema ini, penelitian berfokus pada pembuatan, perancangan atau penerapan aplikasi akuntansi berbasis online di instansi, perusahaan atau Usaha Mikro Kecil dan Menengah (UMKM). Peneliti yang membahas sub tema ini 
diantaranya Aini, Rahardja, Arribathi, \& Santoso (2019), Rahardja, Aini, \& Hardini (2018), Arief (2013), Kirana \& Sitanggang (2019), Wibawa et al. (2019), Suhayati \& Riandani (2019), dan Arifin, Jeong, \& Ock (2014). Kedua, evaluasi, monitoring atau mengukur efektivitas. Penelitian dengan sub tema ini memusatkan perhatiannya pada efektivitas, monitoring dan evaluasi penerapan cloud accounting terhadap proses yang dilakukan atau laporan yang dihasilkan. Peneliti yang membahas sub tema ini antara lain Rahardja, Aini, Azizah, \& Santoso (2018), Rahardja, Aini, \& Khoirunisa (2019), Rahmania \& Hariyani (2019), Aini et.al. (2020), Wicaksono, Kartikasary, \& Salma (2020), dan Aini, Anoesyirwan, \& Ana (2019). Ketiga, persepsi pengguna aplikasi dengan mengangkat persepsi dan minat dari pengguna (users) untuk menggunakan cloud accounting dalam pengelolaan usaha mereka. Beberapa peneliti yang membahas yaitu Hamundu et.al. (2020), Wahyuni (2018), dan Prilahardo (2016).

Dari hasil ringkasan tema diatas, secara umum penelitian yang dilakukan di Indonesia masih dalam tahap perancangan sistem, persepsi pengguna dan evaluasi efektivitas aplikasi cloud accounting. Dari sisi latar belakang peneliti masih di dominasi oleh penelitian yang dilakukan oleh peneliti dari bidang ilmu komputer. Hal ini dapat dipahami karena cloud accounting juga sebagai salah satu bentuk penerapan cloud computing yang merupakan tema bidang ilmu komputer.

\section{Pengembangan Penelitian Cloud Accounting di Masa Depan}

Rekomendasi yang diberikan Knudsen (2020) bahwa perlu adanya penelitian dan pengembangan studi mengenai pengaruh digitalisasi di bidang akuntansi saat ini dan dimasa yang akan datang, harus menjadi perhatian para peneliti. Beberapa tema yang bisa diangkat dalam penelitian menurut Knudsen (2020) dan Moll \& Yigitbasioglu (2019) antara lain: dampak digitalisasi terhadap akuntansi dari sisi internal dan eksternal perusahaan, dampak digitalisasi dalam pengolahan informasi untuk pengambilan keputusan manajerial, keamanan data perusahaan, manajemen resiko jika meninggalkan seluruh pencatatan manual dan beralih ke digital, perlu tidaknya perubahan standar akuntansi dan audit, persepsi dan adaptasi akuntan, serta persepsi dan adaptasi lembaga profesi akuntan. Beberapa tema penelitian yang menarik untuk diteliti diantaranya adalah dampak cloud accounting terhadap operasional perusahaan dan profesi akuntan.

\section{Dampak Cloud Accounting terhadap Operasional Perusahaan}

Pengaruh perkembangan teknologi cloud telah mengubah pola bisnis perusahaan sejak tahun 2010. Walaupun saat ini masih banyak perusahaan yang masih menyimpan datanya secara mandiri, diperkirakan pada tahun 2030 hampir seluruh perusahaan di dunia akan beralih menggunakan perangkat lunak dan penyimpanan data melalui teknologi cloud (Ackerman, 2019). Penelitian yang dilakukan oleh Ahmed (2020) menunjukkan bahwa keuntungan dari migrasi data ke cloud diantaranya adalah sentralisasi data dan informasi melalui integrasi berbagai proses operasional perusahaan seperti manajemen persediaan, aset tetap dan billing, selain itu juga mengurangi beban dan waktu kerja karyawan, keuntungan lainnya adalah efisiensi biaya untuk pengembangan teknologi informasi (TI). Hasil penelitian lainnya oleh Prichici \& Ionescu (2015) penggunaan teknologi cloud dalam kegiatan operasional seperti manajemen persediaan, aset tetap dan payroll, juga menunjukkan adanya penurunan beban dan waktu kerja serta efisiensi biaya. Penggunaan teknologi 
cloud yang dilakukan oleh gabungan beberapa bank di Nigeria menurunkan biaya infrastruktur dan penyediaan perangkat lunak di masing-masing bank, karena biaya ditanggung bersama diantara bank tersebut sehingga menurunkan biaya operasional dan berdampak pada peningkatan profit (Egiyi \& Udeh, 2020). Di era dimana tantangan dan kondisi bisnis yang kompetitif seperti saat ini, diperlukan penyajian data dan informasi yang andal dan aktual. Kemampuan cloud accounting untuk menampilkan data kondisi keuangan perusahaan secara real-time, membuat stakeholder dapat mengambil keputusan bisnis yang penting dengan lebih cepat dan relevan sesuai dengan kondisi terkini (Dimitriu \& Matei, 2015).

\section{Dampak Cloud Accounting pada Profesi Akuntan}

Berdasarkan penelitian Dimitriu \& Matei (2015) firma akuntansi besar dan lembaga profesi akuntan seperti AICPA (American Institute of Certified Public Accountants) sejak tahun 2014 sudah memberikan perhatian kepada cloud accounting, dengan memberikan panduan bagi akuntan untuk cloud-based assurance service. Firma Akuntansi (seperti Deloitte) memberikan daftar penyedia layanan cloud accounting yang telah diseleksi kepada klien, sebagai referensi bagi klien dalam memilih penyedia jasa yang terpercaya. Teknologi cloud telah memberikan pengaruh yang besar kepada akuntan, yang merubah cara kerja secara keseluruhan. Secara umum ada 3 kategori akuntan dalam menghadapi teknologi cloud (Khanom, 2017). Kategori pertama, sebagian akuntan merasa takut dan khawatir dengan tingkat keamanan teknologi cloud dalam menyimpan dan mengolah data keuangan perusahaan.Tipe akuntan ini cenderung menghindar untuk pengembangan teknologi cloud dalam proses akuntansi. Kategori kedua, kelompok akuntan yang menerima penggunaan teknologi cloud accounting akan tetapi mereka mengkhawatirkan berkurangnya pendapatan profesional yang akan diperoleh. Kelompok ini khawatir jika kemudahan akses dan penggunaan teknologi cloud akan menyebabkan klien beralih untuk mulai mengelola keuangan secara mandiri sehingga menyebabkan berkurangnya pekerjaan dan pendapatan yang diperoleh oleh akuntan. Kategori ketiga, kelompok akuntan ini mendukung pengembangan cloud accounting karena secara signifikan meningkatkan efisiensi dan/atau keuntungan yang mereka peroleh. Kelompok ini terus mengembangkan diri untuk mampu beradaptasi dengan perubahan teknologi yang ada. Dengan kemampuan adaptasi teknologi yang mereka miliki, akan memudahkan mereka untuk memperoleh pekerjaan dan klien sehingga pada akhirnya meningkatkan pendapatan yang diperoleh. Ketakutan yang dihadapi oleh akuntan cukup wajar pada saat munculnya teknologi baru yang merubah tatanan dan cara kerja yang telah sekian lama akuntan lakukan. Akan tetapi jika melihat dari sudut pandang yang lain, munculnya cloud justru merupakan sebuah keuntungan bagi akuntan untuk bekerja dengan lebih efektif dan efisien. Cloud accounting telah memberikan alternatif dengan menampilkan laporan keuangan dalam bentuk tampilan dashboard yang dapat diakses secara real-time kapan saja dan dimana saja oleh akuntan. Kemudahan untuk berkomunikasi, berkolaborasi, dan berbagi data serta informasi dengan sesama akuntan atau dengan pihak perusahaan tanpa perlu menggunakan kertas telah banyak membantu pekerjaan akuntan dalam sisi administrasi (Dimitriu \& Matei, 2015). Dengan berkurangnya kegiatan administrasi akan berpengaruh pada efektivitas pekerjaan, lebih efisien karena seluruh pekerjaan bisa diakses melalui berbagai perangkat teknologi yang terhubung dengan internet 
mengurangi biaya untuk cetak dokumen dan transportasi. Adaptasi yang dilakukan oleh akuntan bukan hanya pada sisi teknologi, akan tetapi juga paradigma dan cara kerja.

Penelitian mengenai cloud accounting di dunia relatif telah jauh lebih berkembang dibandingkan penelitian di Indonesia. Sub tema, metode dan objek yang diteliti jauh lebih bervariasi. Akuntansi sebagai bidang ilmu yang juga mengalami perubahan signifikan atas perkembangan teknologi perlu untuk mengembangkan sub tema penelitian secara lebih spesifik dan sesuai kebutuhan dari profesi dan institusi. Keterbatasan data mengenai perkembangan cloud accounting di Indonesia menjadi tantangan tersendiri bagi peneliti, tapi dengan semakin banyaknya penelitian mengenai cloud accounting dan akuntansi digital diharapkan khazanah keilmuan mengenai tema tersebut juga semakin berkembang.

\section{SIMPULAN}

Perkembangan teknologi dan trend era digitalisasi, telah berdampak pada proses pengolahan data akuntansi di perusahaan. Cloud accounting muncul sebagai bentuk implementasi era digital di bidang akuntansi. Perangkat lunak akuntansi yang terhubung melalui jaringan internet menjadi sebuah alternatif pilihan dibandingkan dengan perangkat lunak tradisional. Biaya murah, kemudahan akses, dan fasilitas yang ditawarkan menyebabkan sebagian perusahaan mulai mengalihkan pengolahan data keuangan dengan teknologi cloud. Dari beberapa penelitian, cloud accounting membantu dalam proses integrasi data dan informasi berbagai kegiatan operasional perusahaan, meningkatkan efisiensi biaya, menurunkan beban kerja dan waktu kerja karyawan. Dibalik segala kelebihan yang dimiliki, cloud accounting juga memiliki resiko dan kendala yang harus dihadapi. Keamanan dan kerahasiaan data merupakan isu penting yang menjadi perhatian para pengguna. Perlu kerja keras dari provider untuk mampu meyakinkan pengguna tentang keamanan sistem yang mereka miliki. Penelitian mengenai cloud accounting di Indonesia masih terbatas dari sisi kuantitas dan kualitas tema. Perkembangan sub tema penelitian cloud accounting di dunia dapat dijadikan sebagai motivasi sekaligus bahan referensi untuk pengembangan cloud accounting di Indonesia. Kurangnya penelitian mengenai cloud accounting dan akuntansi digital di Indonesia merupakan sebuah kesempatan bagi peneliti untuk mengembangkan khazanah keilmuan dibidang ini. Pengembangan tema penelitian bisa dilakukan dari berbagai perspektif baik dari sisi penyedia jasa, pengguna jasa, akuntan dan lembaga profesi akuntan serta stakeholder lainnya.

\section{DAFTAR PUSTAKA}

Ackerman, J. L. (2019). Ten Technology Predictions for the Next Decade - The CPA Journal. Retrieved September 2, 2020, from https://www.cpajournal.com/2019/12/17/ten-technology-predictionsfor-the-next-decade/ 
Ahmed, P. I. (2020). Reducing Costs by the Use of Cloud Accounting. Journal of Arts, Literature, Humanities and Social Sciences, 54. https://doi.org/10.33193/JALHSS.54.2020.150

Aini, Q., Anoesyirwan, A., \& Ana, Y. (2019). Effect of Cloud Accounting as income statement on Accountant Performance. Aptisi Transactions on Management (ATM). https://doi.org/10.33050/atm.v4i1.920

Aini, Q., Rahardja, U., Aisyah, E. S., \& Khoirunisa, A. (2020). Performa Kinerja Admin Layanan Keuangan Mahasiswa Menggunakan Dashboard Pada Web Based Accounting Online. Informatika Mulawarman : Jurnal Ilmiah Ilmu Komputer, 15(1), 21. https://doi.org/10.30872/jim.v15i1.1911

Aini, Q., Rahardja, U., Arribathi, A. H., \& Santoso, N. P. L. (2019). Penerapan Cloud Accounting dalam Menunjang Efektivitas Laporan Neraca pada Perguruan Tinggi. Computer Engineering, Science and System Journal. https://doi.org/10.24114/cess.v4i1.12051

Arief, K. (2013). Pengembangan Model Sistem Informasi Akuntansi Online Untuk Usaha Kecil Menengah. Sigma-Mu, 5(2), 133-144.

Arifin, R. A. P., Jeong, S., \& Ock, Y. (2014). Suggestion of Mobile Cloud Accounting Application for Small Medium Micro Enterprises(SMMEs) in Indonesia. The Journal of Internet Electronic Commerce Resarch, 14(5), 147-160.

Bean, L. (2010). Cloud computing: Retro revival or the new paradigm? Journal of Corporate Accounting \& Finance, 21(5), 9-14. https://doi.org/10.1002/jcaf.20605

Christauskas, C., \& Miseviciene, R. (2012). Cloud-Computing Based Accounting for Small to Medium Sized Business. Engineering Economics, 23(1). https://doi.org/10.5755/j01.ee.23.1.1220

Dimitriu, 0., \& Matei, M. (2014). A New Paradigm for Accounting through Cloud Computing. Procedia Economics and Finance, 15, 840-846. https://doi.org/10.1016/S2212-5671(14)00541-3

Dimitriu, O., \& Matei, M. (2015). Cloud Accounting: A New Business Model in a Challenging Context. Procedia Economics and Finance, 32, 665-671. https://doi.org/10.1016/S2212-5671(15)01447-1

Egiyi, M. A., \& Udeh, S. N. (2020). Overview of Cloud Accounting in Nigeria. International Journal of Academic Management Science Research (IJAMSR), $4(6), 81-88$.

Granlund, M., \& Mouritsen, J. (2003). Special section on management control and new information technologies. European Accounting Review, 12(1), 77-83. https://doi.org/10.1080/0963818031000087925

Hamundu, F. M., Husin, M. H., Baharudin, A. S., \& Khaleel, M. (2020). Intention to Adopt Cloud Accounting: A Conceptual Model from Indonesian MSMEs Perspectives. The Journal of Asian Finance, Economics and Business. https://doi.org/10.13106/jafeb.2020.vol7.no12.749

Karimi, J., \& Walter, Z. (2015). The Role of Dynamic Capabilities in Responding to Digital Disruption: A Factor-Based Study of the Newspaper Industry. Journal of Management Information Systems, 32(1), 39-81. https://doi.org/10.1080/07421222.2015.1029380

Khanom, T. (2017). Cloud Accounting: A Theoretical Overview. IOSR Journal of Business and Management, 19(06), 31-38. https://doi.org/10.9790/487X- 


\section{8}

Kirana, D. J., \& Sitanggang, K. (2019). Pendampingan Penerapan Laporan Keuangan Di Era Digital Bagi Umkm Ciracas. In Seminar Nasional Pengabdian Kepada Masyarakat (pp. 49-53).

Knudsen, D.-R. (2020). Elusive boundaries, power relations, and knowledge production: A systematic review of the literature on digitalization in accounting. International Journal of Accounting Information Systems, 36, 100441. https://doi.org/10.1016/j.accinf.2019.100441

Moll, J., \& Yigitbasioglu, 0. (2019). The role of internet-related technologies in shaping the work of accountants: New directions for accounting research. British Accounting Review. https://doi.org/10.1016/j.bar.2019.04.002

Popivniak, Y. (2019). Cloud-Based Accounting Software: Choice Options In The Light Of Modern International Tendencies. Baltic Journal of Economic Studies, 5(3), 170. https://doi.org/10.30525/2256-0742/2019-5-3-170177

Porter, M. E., \& Heppelmann, J. E. (2014). How smart, connected products are transforming competition. Harvard Business Review.

Prichici, C., \& Ionescu, B. (2015). Cloud Accounting-A New Paradigm Of Accounting Policies Literature Review. SEA - Practical Application of Science.

Prilahardo, R. (2016). Tinjauan Sistem Informasi Akuntansi UMKM Berbasis Cloud. BIP's Jurnal Bisnis Perspektif. https://doi.org/10.37477/bip.v8i2.7

Rahardja, U., Aini, Q., Azizah, N., \& Santoso, N. P. L. (2018). Efektivitas Akuntansi Online dalam Menunjang Proses Rekonsiliasi. NJCA (Nusantara Journal of Computers and Its Applications). https://doi.org/10.36564/njca.v3i2.69

Rahardja, U., Aini, Q., \& Hardini, M. (2018). Penerapan Software Akuntansi Online Sebagai Penunjang Pencatatan Laporan Keuangan. SISFOTENIKA. https://doi.org/10.30700/jst.v8i2.408

Rahardja, U., Aini, Q., \& Khoirunisa, A. (2019). Monitoring Kinerja User Akuntan Menggunakan Dashboard Pada Web Based Accounting Online di Perguruan Tinggi. SATIN - Sains Dan Teknologi Informasi. https://doi.org/10.33372/stn.v4i2.406

Rahmania, D., \& Hariyani, F. E. (2019). Keefektifan Penyusunan Laporan Keuangan Menggunakan Sleekr Accounting. In Progress Conference (pp. 232-237).

Sadighi, M. (2014). Accounting System on Cloud: A Case Study. In 2014 11th International Conference on Information Technology: New Generations (pp. 629-632). IEEE. https://doi.org/10.1109/ITNG.2014.26

Singerová, J. (2018). Accounting in Cloud. European Financial and Accounting Journal. https://doi.org/10.18267/j.efaj.206

Suhayati, E., \& Riandani, I. (2019). Accounting Application for Small Medium Enterprises. IOP Conference Series: Materials Science and Engineering, 662, 032056. https://doi.org/10.1088/1757-899X/662/3/032056

Wahyuni, T. (2018). Why Should MSMEs Adopt Accounting Application with Cloud Computing? The Reality of MSMEs in Depok, West Java. KnE Social Sciences. https://doi.org/10.18502/kss.v3i11.2858

Wibawa, B. M., Baihaqi, I., Hanoum, S., Ardiantono, D. S., Kunaifi, A., Persada, S. F., ... Nareswari, N. (2019). Model Pelatihan dan Pendampingan Penyusunan Laporan Keuangan Berbasis Cloud Bagi Pelaku UMKM. SEWAGATI, Jurnal 
Pengabdian Kepada Masyarakat - LPPM ITS, 3(3), 51-56.

Wicaksono, A., Kartikasary, M., \& Salma, N. (2020). Analyze cloud accounting software implementation and security system for accounting in MSMEs and cloud accounting software developer. In Proceedings of 2020 International Conference on Information Management and Technology, ICIMTech 2020. https://doi.org/10.1109/ICIMTech50083.2020.9211271

Wyslocka, E., \& Jelonek, D. (2015). Accounting in the Cloud Computing. TOJSAT, $5(4)$. 